И. А. Машкин, В. П. Шуканов, Е. В. Мельникова, Л. А. Корытько, С. Н. Полянская Институт экспериментальной ботаники имени В. Ф. Купревича НАН Беларуси

\title{
ИЗМЕНЕНИЕ МОРФОБИОМЕТРИЧЕСКИХ И ФИЗИОЛОГО-БИОХИМИЧЕСКИХ ПАРАМЕТРОВ СЕЯНЦЕВ СОСНЫ (PINUS SYLVESTRIS L.) ПРИ ОБРАБОТКЕ ЗАЩИТНО-СТИМУЛИРУЮЩИМИ СОСТАВАМИ
}

В данной статье представлены результаты исследования влияния обработок посевного и посадочного материала сосны обыкновенной (Pinus sylvestris L.) регуляторами роста и фунгицидами. Опыты проводили в условиях открытого грунта в 2020 г. на территории постоянного питомника ГЛХУ «Логойский лесхоз». Перед высевом часть семян, относящихся к первому классу качества, инкрустировали защитно-стимулирующим составом, включающим регулятор роста Экосил Микс и фунгицид Винцит Форте. Параллельно в нескольких вариантах на 30-е и 60-е сут посредством опрыскивания вегетирующих растений вносили растворы регуляторов роста Экосил Микс или Экосил Плюс. Сеянцы выращивали в полевых условиях на протяжении 90 дней, затем у них измеряли морфобиометрические и физиолого-биохимические параметры.

В итоге было установлено, что Винцит Форте, а также Экосил Микс и Экосил Плюс оказывают существенное влияние на параметры сеянцев сосны обыкновенной. Зависимость прослеживается как от сочетания препаратов, так и от кратности внекорневых обработок. Наибольший положительный эффект достигнут при отдельном опрыскивании вегетирующих растений Экосилами и инкрустации семян смесью Экосила Микс и Винцита Форте. Активация роста сеянцев сопровождалась нормализацией фотосинтетических и окислительных процессов на фоне повышения целостности мембран растительных клеток.

Ключевые слова: семена, сеянцы, сосна, регуляторы роста, фунгициды, пигменты фотосинтеза, перекисное окисление липидов, мембраны клеток.

Для цитирования: Машкин И. А., Шуканов В. П., Мельникова Е. В., Корытько Л. А., Полянская С. Н. Изменение морфобиометрических и физиолого-биохимических параметров сеянцев сосны (Pinus sylvestris L.) при обработке защитно-стимулирующими составами // Труды БГТУ. Сер. 1, Лесное хоз-во, природопользование и перераб. возобновляемых ресурсов. 2021. № 2 (246). С. 73-80.

I. A. Mashkin, V. P. Shukanov, E. V. Mel'nikova, L. A. Koryt'ko, S. N. Polyanskaya

V. F. Kuprevich Institute of Experimental Botany of the National Academy of Sciences of Belarus

\section{CHANGES OF MORPHOBIOMETRIC, PHYSIOLOGICAL AND BIOCHEMICAL PARAMETERS OF PINE SEEDLINGS (PINUS SYLVESTRIS L.) WHEN APPLICATION PROTECTIVE-STIMULATING COMPOSITIONS}

This article presents the results of research of the effect of treatments of seed and planting material of Scots pine (Pinus sylvestris L.) with growth regulators and fungicides. The experiments were carried out in open ground in 2020 on the territory of the permanent nursery of the State Forestry Institution "Logoisk forestry". Before sowing, some of the seeds belonging to the first quality class were encrusted with a protective and stimulating composition, including the growth regulator Ecosil Mix and the fungicide Vincit Forte. In parallel, on the 30th and 60th days, solutions of Ecosil Mix or Ecosil Plus were introduced by spraying vegetative plants in several variants. Seedlings were grown in field conditions for 90 days, after were measured morphobiometric as well physiological and biochemical parameters.

As a result, it was found that treatments with the Vincit Forte, as well Ecosil Mix and Ecosil Plus, have a significant effect on parameters of Scots pine seedlings. The dependence can be traced both on the combination of drugs and on the frequency of foliar treatments. The greatest growth-stimulating effect is observed when vegetating plants are sprayed with Ecosil and seeds of Ecosil Mix and Vincita Forte. The activation of seedling growth was accompanied by a noticeable improvement in photosynthetic and oxidative processes, as well an increase in the integrity of plant cell membranes.

Key words: seeds, seedling, pine, growth regulators, fungicides, photosynthesis pigments, lipid peroxidation, cell membranes.

For citation: Mashkin I. A., Shukanov V. P., Mel'nikowa E. V., Koryt'ko L. A., Polyanskaya S. N. Changes of morphobiometric, physiological and biochemical parameters of pine seedlings (Pinus sylvestris L.) when application protective-stimulating compositions. Proceedings of BSTU, issue 1, Forestry. Nature Management. Processing of Renewable Resources, 2021, no. 2 (246), pp. 73-80 (In Russian). 
Введение. Регулирование роста, а также уменьшение влияния негативных факторов окружающей среды являются важными звеньями в онтогенезе растений, определяющими их продуктивность. Общепризнано, что биотический и абиотический стресс не позволяет растениям достичь всего потенциала, однако, к сожалению, текущее понимание задействованных механизмов и стратегий смягчения этих эффектов весьма ограничено. Стресс можно частично предотвратить путем оптимизации технологий выращивания растений, обеспечивая их водой и питательными веществами. Дополнительно к этим традиционным подходам все чаще в производственные системы с целью изменения физиолого-биохимических процессов растений и повышения продуктивности интегрируются биостимуляторы [1-3].

На данный момент в той или иной степени изучено около 5000 соединений синтетического или природного происхождения, обладающих росторегулирующим действием $[4,5]$. Следует помнить, что использование химических веществ при выращивании растений должно ориентироваться на принципы экологической безопасности, поэтому регуляторы роста на основе природного сырья привлекают большое внимание как научного сообщества, так и коммерческих предприятий, особенно в последние десятилетия [1]. Одними из наиболее перспективных являются препараты, действующим веществом которых выступает комплекс тритерпеновых кислот. К ним, например, относятся отечественные регуляторы роста, выпускаемые УП «Белуниверсалпродукт» под маркой Экосил. Сырьем для их производства служит хвоя пихты сибирской (Abies sibirica), что позволило присвоить Экосилам 4-й класс опасности $[4,5]$.

Препараты, содержащие тритерпеновые кислоты пихты, наряду с росторегулирующим должны обеспечивать также иммунопротекторное действие $[5,6]$. Тем не менее без целенаправленного ингибирования патогенов, в особенности грибов, растения теряют часть своей продуктивности, даже с учетом возросшей благодаря росторегуляторам устойчивости. Поэтому логично возникает вопрос о необходимости применения фунгицидов для обработки растений прежде всего перед высевом семян, так как широкий сектор фитопатогенов может не только снизить качество посевного материала, но и способствовать развитию болезней сеянцев $[2,7,8]$. Вместе с тем довольно часто в научной литературе сообщается о негативном влиянии пестицидов на первичный метаболизм растений. Так, изменения фотосинтетического аппарата могут приводить к сокращению производства фотоассимилятов и, как следствие, падает интенсивность ростовых процессов. Однако, к сожалению, на данный момент большинство исследований влияния регуляторов роста и фунгицидов опираются прежде всего на морфобиометрические показатели, в то время как наиболее точно охарактеризовать действие защитно-стимулирующих веществ можно на физиолого-биохимическом уровне $[2,3]$.

Основная часть. Объектами исследования являлись сенцы сосны обыкновенной (Pinus sylvestris L.) с открытой корневой системой, выращенные на территории постоянного питомника ГЛХУ «Логойский лесхоз». Семена, относящиеся к первому классу, высеяны в мае 2020 г. безгрядковым ленточным посевом по пятистрочной схеме, с расстоянием 25 см и шириной строки, равной 5 см. В пределах опытного участка общей площадью 0,3 га случайным образом были разбиты метровые делянки (по 4 на один вариант). Продолжительность эксперимента составила 90 дней.

Перед посевом часть семян инкрустировали защитно-стимулирующими составами, включающими фунгицид Винцит Форте и регулятор роста Экосил Микс. В июне - начале августа произвели внекорневую обработку сеянцев путем опрыскивания вегетирующей массы растений рабочими растворами препаратов Экосил Микс и Экосил Плюс одно- двукратно с интервалом в 20-30 дней согласно составленной схеме опытов (табл. 1).

Винцит Форте, КС (флутриафол 37,5 г/л + + тиабендазол 25 г/л + имазалил 15 г/л) - системный фунгицид для защиты растений от комплекса заболеваний, передающихся с семенами через почву и аэрогенным путем. Протравитель проявляет фунгицидный эффект в течение нескольких часов после высева протравленных семян. Обладают профилактическим и лечащим действием [9].

Экосил Микс, ВЭ (5 г/л тритерпеновых кислот) - природный полифункциональный препарат, регулятор роста и индуктор иммунитета растений. Обогащен комплексом макро- и микроэлементов и широким спектром биологически активных соединений: модифицированных гуминовых кислот, фульвокислот, аминокислот и биогенных аминов (тирамин и др.), низкомолекулярных органических кислот (янтарная, малоновая, яблочная, щавелевая, и др.), фенолкарбоновых кислот [10].

Экосил Плюс, ВЭ $(2,5$ г/л тритерпеновых кислот) - регулятор роста, в состав которого, помимо тритерпеновых кислот, входит биологически активная сумма нейтральных изопреноидов, обогащенная композицией из более чем 30 легколетучих малополярных, моно- и группа сесквитерпеновых соединений [11]. 
Схема проведения опыта по обработке семян и сеянцев сосны

Таблица 1

\begin{tabular}{|c|c|c|}
\hline Вариант & Способ обработки & $\begin{array}{c}\text { Расход } \\
\text { рабочего раствора }\end{array}$ \\
\hline Контроль (сухие семена) & - & - \\
\hline Экосил Микс 1,0 л/га (1 обработка) & Внекорневая & $30 \mathrm{Mл} / \mathrm{M}^{2}$ \\
\hline Экосил Микс 1,0 л/га (2 обработки) & Внекорневая & $30 \mathrm{мл/ \textrm {M } ^ { 2 }}$ \\
\hline Экосил Плюс 1,5 л/га (1 обработка) & Внекорневая & $30 \mathrm{мл} / \mathrm{M}^{2}$ \\
\hline Экосил Плюс 1,5 л/га (2 обработки) & Внекорневая & 30 мл/ $\mathrm{M}^{2}$ \\
\hline Экосил Микс 0,1 мл/л + Винцит Форте 50 мл/л & Предпосевная (инкрустация) & 10 мл/кг \\
\hline $\begin{array}{l}\text { Экосил Микс 0,1 мл/л + Винцит Форте } 50 \text { мл/л + Эко- } \\
\text { сил Микс } 1,0 \text { л/га (1 обработка) }\end{array}$ & $\begin{array}{l}\text { Предпосевная (инкрустация) + вне- } \\
\text { корневая }\end{array}$ & $\begin{array}{l}10 \mathrm{мл/кГ} \\
30 \mathrm{мл} / \mathrm{M}^{2}\end{array}$ \\
\hline $\begin{array}{l}\text { Экосил Микс 0,1 мл/л + Винцит Форте } 50 \text { мл/л + Эко- } \\
\text { сил Микс } 1,0 \text { л/га (2 обработки) }\end{array}$ & $\begin{array}{l}\text { Предпосевная (инкрустация) + вне- } \\
\text { корневая }\end{array}$ & $\begin{array}{l}10 \text { мл/кг } \\
30 \mathrm{мл} / \mathrm{M}^{2}\end{array}$ \\
\hline $\begin{array}{l}\text { Экосил Микс } 0,1 \text { мл/л + Винцит Форте } 50 \text { мл/л + Эко- } \\
\text { сил Плюс 1,5 л/га (1 обработка) }\end{array}$ & $\begin{array}{l}\text { Предпосевная (инкрустация) + вне- } \\
\text { корневая }\end{array}$ & $\begin{array}{l}10 \text { мл/кг } \\
30 \mathrm{мл} / \mathrm{M}^{2}\end{array}$ \\
\hline $\begin{array}{l}\text { Экосил Микс } 0,1 \text { мл/л + Винцит Форте } 50 \text { мл/л + Эко- } \\
\text { сил Плюс } 1,5 \text { л/га (2 обработки) }\end{array}$ & $\begin{array}{l}\text { Предпосевная (инкрустация) + вне- } \\
\text { корневая }\end{array}$ & $\begin{array}{l}10 \mathrm{мл/кГ} \\
30 \mathrm{мЛ} / \mathrm{M}^{2}\end{array}$ \\
\hline
\end{tabular}

На 90-е сут выращивания у сенцев были измерены морфобиометрические (длина надземной и подземной части, толщина корневой шейки) и физиолого-биохимические параметры (содержание пигментов фотосинтеза и продуктов перекисного окисления липидов в хвое, проницаемость мембран клеток).

Обмер случайно отобранного посадочного материала (10 сеянцев с делянки) производили измерительными инструментами: длину надземной и подземной части - с помощью линейки с миллиметровыми делениями, диаметр корневой шейки - штангенциркулем. Длину надземной части измеряли по оси стволика от корневой шейки до основания верхушечной почки, а подземной части - от корневой шейки до окончания корня.

Физиолого-биохимические параметры оценивали с помощью спектрофотометрических и кондуктометрических методов. Для определения содержания пигментов фотосинтеза образцы хвои с постоянной навеской 0,2 г отбирали в трехкратной повторности. Далее в лабораторных условиях получали вытяжку пигментов в ацетоне. Экстракты пигментов фильтровались вакуумным способом, а после определяли оптическую плотность вытяжек на спектрофотометре Proscan MC 122. Количество отдельных пигментов устанавливали с помощью трехволнового метода, измеряя оптическую плотность (D) вытяжки при длине волн 662, 644 и 440 нм (максимумы поглощения соответственно хлорофилла $a$, хлорофилла $b$ и каротиноидов в ацетоне). Концентрацию хлорофиллов $a$ и $b$ и их сумму рассчитывали по уравнениям Винтерманс и Де Мотс для ацетона, а концентрацию каротиноидов в суммарной вытяжке пигментов вычисляли по уравнению Веттштейна [12-15].
Интенсивность перекисного окисления липидов определяли, основываясь на способности 2-тиобарбитуровой кислоты (ТБК) связываться с липидными перекисями (малоновый диальдегид). Образующиеся окрашенные ТБК-продукты являлись тестом активности протекания данного процесса. Пробу свежей массы, отобранную в трехкратной повторности, растирали до гомогената в $0,25 \%$ ТБК и $10 \%$ трихлоруксусной кислоты (ТХУ). Затем пробы нагревали 30 мин при $95^{\circ} \mathrm{C}$, после чего охлаждали в проточной воде и доводили до метки дистиллированной водой, а затем центрифугировали на протяжении 15 мин при 8000 g. Получившийся супернатант спектрофотометрировали при длине волн, равной 532 нм. Количество ТБК-продуктов (мкМ/г свежей массы) рассчитывали, используя молярный коэффициент экстинкции $1,55 \cdot 10^{5} \mathrm{M}-1$ см-1 [12-14, 16, 17].

Проницаемость мембран растительных клеток фиксировали по выходу водорастворимых веществ из свежей хвои. Для этого контрольные и опытные образцы помещали в дистиллированную воду (соотношение воды и навески составляло $50: 1$ ) и инкубировали в ней 3 ч. После чего хвою удаляли и проводили измерения кондуктометром НI-8734 (в мг/л), при этом учитывали показания, полученные для дистиллированной воды [2, 3, 12-14].

Для статистического анализа полученных в ходе экспериментов результатов были рассчитаны ошибка среднего (уровень надежности 95\%), парный двухвыборочный $t$-критерий Стьюдента средних значений (уровень значимости 0,05 ) и корреляционная матрица (интерпретация согласно шкале Чеддока) на базе программного обеспечения пакета анализа Microsoft Excel 2013 [3, 18]. 
Таблица 2

Влияние обработок на морфобиометрические параметры сеянцев сосны (3 мес.)

\begin{tabular}{|c|c|c|c|c|c|c|}
\hline \multirow{2}{*}{ Варианты опыта } & \multicolumn{2}{|c|}{$\begin{array}{c}\text { Длина } \\
\text { надземной части }\end{array}$} & \multicolumn{2}{|c|}{$\begin{array}{l}\text { Длина } \\
\text { корня }\end{array}$} & \multicolumn{2}{|c|}{$\begin{array}{c}\text { Толщина } \\
\text { корневой шейки }\end{array}$} \\
\hline & $\operatorname{MM}(M \pm m)$ & $\begin{array}{l}\% \text { к к } \\
\text { конт. }\end{array}$ & мм $(M \pm m)$ & $\begin{array}{l}\% \text { \% к } \\
\text { конт. }\end{array}$ & мм $(M \pm m)$ & $\begin{aligned} \% \text { к } \\
\text { конт. }\end{aligned}$ \\
\hline Контроль (сухие семена) & $68,83 \pm 1,15$ & 100 & $54,70 \pm 2,82$ & 100 & $0,80 \pm 0,01$ & 100 \\
\hline Экосил Микс 1,0 л/га (1 обработка) & $72,90 \pm 1,28^{*}$ & 106 & $66,83 \pm 2,44^{*}$ & 122 & $0,91 \pm 0,01^{*}$ & 114 \\
\hline Экосил Микс 1,0 л/га (2 обработки) & $68,83 \pm 0,98$ & 100 & $71,03 \pm 2,09^{*}$ & 130 & $0,83 \pm 0,01$ & 105 \\
\hline Экосил Плюс 1,5 л/га (1 обработка) & $66,45 \pm 0,79$ & 97 & $79,78 \pm 1,36^{*}$ & 146 & $0,86 \pm 0,02 *$ & 108 \\
\hline Экосил Плюс 1,5 л/га (2 обработки) & $72,43 \pm 1,20^{*}$ & 105 & $78,45 \pm 2,11^{*}$ & 143 & $0,93 \pm 0,01^{*}$ & 117 \\
\hline $\begin{array}{l}\text { Экосил Микс } 0,1 \text { мл/л + Винцит Форте } \\
50 \text { мл/л }\end{array}$ & $75,38 \pm 1,09 *$ & 110 & $77,28 \pm 1,50^{*}$ & 141 & $0,93 \pm 0,01 *$ & 117 \\
\hline $\begin{array}{l}\text { Экосил Микс } 0,1 \text { мл/л + Винцит Форте } \\
50 \text { мл/л + Экосил Микс } 1,0 \text { л/га (1 обра- } \\
\text { ботка) }\end{array}$ & $68,15 \pm 1,03$ & 99 & $53,45 \pm 1,26$ & 98 & $0,80 \pm 0,01$ & 100 \\
\hline $\begin{array}{l}\text { Экосил Микс } 0,1 \text { мл/л + Винцит Форте } \\
50 \text { мл/л + Экосил Микс 1,0 л/га (2 обра- } \\
\text { ботки) }\end{array}$ & $58,73 \pm 0,75^{*}$ & 85 & $40,85 \pm 1,46^{*}$ & 75 & $0,78 \pm 0,01$ & 98 \\
\hline $\begin{array}{l}\text { Экосил Микс } 0,1 \text { мл/л + Винцит Форте } \\
50 \text { мл/л + Экосил Плюс } 1,5 \text { л/га (1 обра- } \\
\text { ботка) }\end{array}$ & $70,88 \pm 0,96$ & 103 & $51,35 \pm 2,60$ & 94 & $0,88 \pm 0,01^{*}$ & 111 \\
\hline $\begin{array}{l}\text { Экосил Микс } 0,1 \text { мл/л + Винцит Форте } \\
50 \text { мл/л + Экосил Плюс } 1,5 \text { л/га (2 обра- } \\
\text { ботки) }\end{array}$ & $59,83 \pm 1,09 *$ & 87 & $42,23 \pm 1,72 *$ & 77 & $0,76 \pm 0,01$ & 96 \\
\hline
\end{tabular}

* Данные статистически значимы по $t$-критерию Стьюдента $(p=0,05)$.

В возрасте 3 мес. у сеянцев сосны обыкновенной с открытой корневой системой под действием защитно-стимулирующих препаратов отмечена существенная интенсификация ростовых процессов как в вариантах с одной только предпосевной или внекорневой обработкой, так и при однократном параллельном внесении Экосила Плюс во время вегетации (табл. 2). При этом длина надземной части наиболее заметно увеличилась в сравнении с контролем при отдельном инкрустировании посевного материала смесью Экосила Микс и Винцита Форте (до $10 \%)$, а длина корня оказалась максимальной после однократной внекорневой обработки регулятором роста Экосил Плюс. В свою очередь самое ощутимое утолщение корневой шейки сеянцев зафиксировано как при отдельной двукратной экзогенной обработке растений Экосилом Плюс, так и после инкрустирования семян, но без последующего опрыскивания растений растворами регуляторов роста. Однако следует отметить, что параллельные предпосевные и двукратные внекорневые обработки вызвали некоторое ингибирование ростовых процессов сосны обыкновенной, а в вариантах с однократным внесением регуляторов роста получены показатели, близкие к контрольным значениям. Исключением стал лишь вариант Экосил Микс 0,1 мл/л + Винцит Форте 50 мл/л + Экосил Плюс 1,5 л/га (1 обработка), в котором наблюдается статистически значимое по отношению к контрольным показателям увеличение толщины корневой шейки сеянцев сосны обыкновенной (до $11 \%$ ).

На физиолого-биохимическом уровне влияние обработок заметно прежде всего по изменению содержания пигментов фотосинтеза в хвое сеянцев (табл. 3), которое указывает на смещение первичных метаболических путей растений при внесении испытываемых препаратов. Статистически достоверное колебание количества фотосинтетических пигментов относительно контроля как в большую, так и в меньшую сторону, зафиксировано в большинстве опытных вариантов. Следует отметить, что в случае отдельного внесения Экосилов во время вегетации прослеживается зависимость от кратности обработок, а при сочетании экзогенных обработок с инкрустированием уже от используемого для опрыскивания регулятора роста. Так, однократные внекорневые обработки биостимуляторами вызвали падение уровня содержания пигментов фотосинтеза, а двукратные, напротив, привели к существенному повышению концентрации хлорофиллов. При этом опрыскивание Экосилом Микс в сочетании с предпосевной обработкой обусловило сокращение содержания фотосинтетических пигментов относительно контроля, а параллельное внесение Экосила Плюс - повышение. 
Влияние обработок на содержание пигментов фотосинтеза в хвое сеянцев сосны (3 мес.)

\begin{tabular}{|c|c|c|c|c|c|c|}
\hline \multirow[b]{2}{*}{ Варианты опыта } & \multicolumn{2}{|c|}{ Хлорофилл $a$} & \multicolumn{2}{|c|}{ Хлорофилл $b$} & \multicolumn{2}{|c|}{ Каротиноиды } \\
\hline & $\mathrm{M} \Gamma / \Gamma(M \pm m)$ & $\begin{array}{c}\% \\
\text { к конт. }\end{array}$ & $\mathrm{M \Gamma} / \Gamma(M \pm m)$ & $\begin{array}{c}\% \\
\text { к конт. }\end{array}$ & $\mathrm{M \Gamma} / \Gamma(M \pm m)$ & $\begin{array}{c}\% \\
\text { к конт }\end{array}$ \\
\hline Контроль (сухие семена) & $0,50 \pm 0,01$ & 100 & $0,15 \pm 0,01$ & 100 & $0,40 \pm 0,01$ & 100 \\
\hline Экосил Микс 1,0 л/га (1 обработка) & $0,40 \pm 0,01 *$ & 79 & $0,12 \pm 0,01^{*}$ & 84 & $0,32 \pm 0,01 *$ & 80 \\
\hline Экосил Микс 1,0 л/га (2 обработки) & $0,52 \pm 0,01$ & 103 & $0,16 \pm 0,01 *$ & 109 & $0,41 \pm 0,01$ & 102 \\
\hline Экосил Плюс 1,5 л/га (1 обработка) & $0,43 \pm 0,01^{*}$ & 85 & $0,13 \pm 0,01^{*}$ & 92 & $0,36 \pm 0,01^{*}$ & 89 \\
\hline Экосил Плюс 1,5 л/га (2 обработки) & $0,53 \pm 0,01^{*}$ & 105 & $0,16 \pm 0,01 *$ & 113 & $0,42 \pm 0,01$ & 104 \\
\hline $\begin{array}{l}\text { Экосил Микс } 0,1 \text { мл/л + Винцит Форте } \\
50 \text { мл/л }\end{array}$ & $0,55 \pm 0,01 *$ & 109 & $0,16 \pm 0,01^{*}$ & 112 & $0,40 \pm 0,01$ & 101 \\
\hline $\begin{array}{l}\text { Экосил Микс } 0,1 \text { мл/л + Винцит Форте } \\
50 \text { мл/л + Экосил Микс 1,0 л/га (1 обра- } \\
\text { ботка) }\end{array}$ & $0,47 \pm 0,01 *$ & 93 & $0,15 \pm 0,01$ & 102 & $0,38 \pm 0,01^{*}$ & 94 \\
\hline $\begin{array}{l}\text { Экосил Микс } 0,1 \text { мл/л + Винцит Форте } \\
50 \text { мл/л + Экосил Микс 1,0 л/га (2 обра- } \\
\text { ботки) }\end{array}$ & $0,41 \pm 0,01 *$ & 82 & $0,12 \pm 0,01^{*}$ & 81 & $0,32 \pm 0,01 *$ & 81 \\
\hline $\begin{array}{l}\text { Экосил Микс } 0,1 \text { мл/л + Винцит Форте } \\
50 \text { мл/л + Экосил Плюс 1,5 л/га (1 обра- } \\
\text { ботка) }\end{array}$ & $0,55 \pm 0,01 *$ & 110 & $0,19 \pm 0,01^{*}$ & 131 & $0,43 \pm 0,01^{*}$ & 107 \\
\hline $\begin{array}{l}\text { Экосил Микс } 0,1 \text { мл/л + Винцит Форте } \\
50 \text { мл/л + Экосил Плюс 1,5 л/га (2 обра- } \\
\text { ботки) }\end{array}$ & $0,57 \pm 0,01^{*}$ & 114 & $0,19 \pm 0,01^{*}$ & 133 & $0,43 \pm 0,01^{*}$ & 108 \\
\hline
\end{tabular}

* Данные статистически значимы по $t$-критерию Стьюдента $(p=0,05)$.

Отдельное инкрустирование семян смесью регулятора роста Экосил Микс и фунгицида Винцит Форте повлияло только на содержание хлорофиллов, увеличив их количество в хвое сеянцев. Вопрос изменения содержания пигментов фотосинтеза при внесении защитно-стимулирующих веществ и действии стресса остается не до конца раскрытым, поэтому нельзя однозначно интерпретировать полученные результаты. Можно лишь предположить, что в данном случае ведущим фактором к раскрытию потенциала растений является прежде всего количество хлорофиллов, ведь именно их сокращение, в особенности по отношению к каротиноидам, способно привести к разобщению фотосистем и нарушить процессы преобразования энергии. В свою очередь негативно отразиться на растении может и резкое колебание каротиноидов, так как они являются обязательными спутниками хлорофиллов и обеспечивают защиту $[2,3,15]$.

Почти во всех опытных вариантах произведенные обработки посевного и посадочного материала сосны обыкновенной способствовали уменьшению окислительного стресса и увеличению целостности мембран клеток сеянцев с открытой корневой системой в возрасте 3 мес. (табл. 4).

Влияние обработок на окислительные процессы и мембраны клеток сеянцев сосны (3 мес.)

\begin{tabular}{|c|c|c|c|c|}
\hline \multirow{2}{*}{ Варианты опыта } & \multicolumn{2}{|c|}{ Содержание ТБК-продуктов } & \multicolumn{2}{|c|}{ Выход водорастворимых в-в } \\
\hline & $\mathrm{MKM} / \Gamma(M \pm m)$ & $\%$ к конт. & $\mathrm{M \Gamma} / \mathrm{\Omega} / \Gamma(M \pm m)$ & $\%$ к конт. \\
\hline Контроль (сухие семена) & $33,32 \pm 0,30$ & 100 & $5,8 \pm 0,1$ & 100 \\
\hline Экосил Микс 1,0 л/га (1 обработка) & $31,44 \pm 0,58^{*}$ & 94 & $6,0 \pm 0,1$ & 103 \\
\hline Экосил Микс 1,0 л/га (2 обработки) & $30,25 \pm 0,42 *$ & 91 & $4,8 \pm 0,1^{*}$ & 82 \\
\hline Экосил Плюс 1,5 л/га (1 обработка) & $31,96 \pm 0,35$ & 96 & $5,6 \pm 0,1$ & 96 \\
\hline Экосил Плюс 1,5 л/га (2 обработки) & $32,16 \pm 0,36$ & 96 & $5,4 \pm 0,1^{*}$ & 93 \\
\hline Экосил Микс 0,1 мл/л + Винцит Форте 50 мл/л & $30,12 \pm 0,32 *$ & 90 & $5,2 \pm 0,1^{*}$ & 90 \\
\hline $\begin{array}{l}\text { Экосил Микс } 0,1 \text { мл/л + Винцит Форте } 50 \text { мл/л + Эко- } \\
\text { сил Микс } 1,0 \text { л/га (1 обработка) }\end{array}$ & $30,39 \pm 0,24 *$ & 91 & $5,9 \pm 0,1$ & 101 \\
\hline $\begin{array}{l}\text { Экосил Микс } 0,1 \text { мл/л + Винцит Форте } 50 \text { мл/л + Эко- } \\
\text { сил Микс } 1,0 \text { л/га (2 обработки) }\end{array}$ & $33,45 \pm 0,36$ & 100 & $6,3 \pm 0,1$ & 107 \\
\hline $\begin{array}{l}\text { Экосил Микс } 0,1 \text { мл/л + Винцит Форте } 50 \text { мл/л + Эко- } \\
\text { сил Плюс } 1,5 \text { л/га (1 обработка) }\end{array}$ & $39,54 \pm 0,47^{*}$ & 119 & $6,4 \pm 0,1^{*}$ & 109 \\
\hline $\begin{array}{l}\text { Экосил Микс } 0,1 \text { мл/л + Винцит Форте } 50 \text { мл/л + Эко- } \\
\text { сил Плюс } 1,5 \text { л/га (2 обработки) }\end{array}$ & $49,59=$ & 149 & $6,6 \pm 0,2^{*}$ & 113 \\
\hline
\end{tabular}

* Данные статистически значимы по $t$-критерию Стьюдента $(p=0,05)$. 
Таблица 5

Корреляционная матрица измеренных параметров сеянцев сосны (3 мес.)

\begin{tabular}{|l|c|c|c|c|c|c|}
\hline \multicolumn{1}{|c|}{ Показатели } & $\begin{array}{c}\text { Длина } \\
\text { надземной } \\
\text { части }\end{array}$ & $\begin{array}{c}\text { Длина } \\
\text { корня }\end{array}$ & $\begin{array}{c}\text { Толщина } \\
\text { корневой } \\
\text { шейки }\end{array}$ & $\begin{array}{c}\text { Содержание } \\
\text { ТБК- } \\
\text { продуктов }\end{array}$ & $\begin{array}{c}\text { Выход } \\
\text { водорастворимых } \\
\text { веществ }\end{array}$ & $\begin{array}{c}\text { Содержание } \\
\text { пигментов } \\
\text { фотосинтеза }\end{array}$ \\
\hline Длина надземной части & 1,0 & - & - & - & - & - \\
\hline Длина корня & 0,7 & 1,0 & - & - & - & - \\
\hline Толщина корневой шейки & 0,8 & 0,8 & 1,0 & - & - & - \\
\hline Содержание ТБК-продуктов & $-0,5$ & $-0,6$ & $-0,4$ & 1,0 & - & - \\
\hline Выход водоратвор. веществ & $-0,5$ & $-0,8$ & $-0,4$ & 0,7 & 1,0 & - \\
\hline Содержание пигментов фотосинтеза & 0,1 & 0,0 & 0,0 & 0,5 & 0,0 & 1,0 \\
\hline
\end{tabular}

Лишь при сочетании инкрустации семян смесью препаратов Экосил Микс и Винцит Форте и внекорневой обработки посадочного материала растворами Экосила Плюс отмечены существенное повышение содержания в тканях растений продуктов перекисного окисления липидов и более активный выход водорастворимых веществ из хвои сосны в сравнение с контрольными образцами. Видно, что эти два показателя изменяются, как правило, синхронно, причем в сторону увеличения, а вот снижение интенсивности окисления липидов не всегда приводит к явному повышению целостности клеточных мембран. Подобное, например, зафиксировано в случае однократной экзогенной обработки сеянцев росторегулятором Экосил Микс как на фоне инкрустации семян, так и в варианте с отдельным опрыскиванием растений. В целом же наиболее четкое антиоксидантное и мембранотропное действие препаратов заметно при отдельном двукратном внесении Экосила Микс во время вегетации и после комплексной предпосевной обработки семян Экосилом Микс и Винцитом Форте.

Проведенный корреляционный анализ позволил выявить тесноту и направление взаимосвязи между измеренными показателями роста и болезнеустойчивости растений (табл. 5). Так, высокая положительная зависимость установлена между толщиной корневой шейки, длиной надземной и подземной частей сеянцев. Заметно отрицательно соотносятся с величинами морфобиометрических параметров уровень содержания ТБК-продуктов и интенсивность выхода из тканей сеянцев водорастворимых веществ. Также заметно, но уже в положительном направлении, количество ТБК-продуктов коррелирует с остальными физиолого-биохимическими показателями. Данная закономерность вполне ожидаема, так как перекисное окисление липидов приводит к нарушению целостности мембран клеток, что, как правило, является следствием наличия стресса, к которому растительный организм пытается приспособиться, активируя первичный метаболизм, в частности, фотосинтетические процессы $[2,3]$.

Заключение. Обработки фунгицидом Винцит Форте, а также регуляторами роста Экосил Микс и Экосил Плюс оказывают существенное влияние на морфобиометрические и физиолого-биохимические параметры сеянцев сосны обыкновенной с открытой корневой системой на начальных этапах роста. Наибольший положительный эффект достигнут при отдельном опрыскивании вегетирующих растений Экосилами и инкрустации семян защитно-стимулирующим составом, включающим Экосила Микс и Винцита Форте. Активация роста сеянцев, как правило, сопровождалась заметной нормализацией фотосинтетических и окислительных процессов на фоне повышения целостности мембран растительных клеток. Таким образом, испытанные препараты обладают антиоксидантным, мембранотропным, росто- и иммуностимулирующим действием, а их использование является целесообразным агротехническим приемом, который должен способствовать повышению качества посевного и посадочного материала хвойных пород растений при полной экологической безопасности.

\section{Список литературы}

1. Yakhin Oleg I., Lubyanov Aleksandr A., Yakhin Ildus A., Brown Patrick H. Biostimulants in Plant Science: A Global Perspective // Frontiers in Plant Science. 2017. Vol. 7. P. 1-32.

2. Волынец А. П., Шуканов В. П. Физиология патогенеза и болезнеустойчивости растений. Минск: Беларуская навука, 2016. 252 с.

3. Эндогенные фиторегуляторы роста: свойства, физиологическое действие и практическое использование / А. П. Волынец [и др.]. Минск: Беларуская навука, 2019. 233 с.

4. Дударевич В. И., Позняк С. С., Романовский Ч. А. Влияние регулятора роста Экосил на формирование фотосинтетического аппарата и продуктивность среднеспелых сортов картофеля // Вестник АПК Верхневолжья. 2008. № 1. С. 19-24. 
5. Чукичева И. Ю., Хуршкайнен Т. В., Кучин А. В. Природные регуляторы роста растений из хвойного сырья // Инноватика и экспертиза. 2018. № 3 (24). С. 93-99.

6. Ралдугин В. А. Тритерпеноиды пихты и высокоэффективный регулятор роста растений на их основе // Российский химический журнал. 2004. № 3. С. 84-88.

7. Ламан Н. А., Алексейчук Г. Н., Калацкая Ж. Н. Современная технология предпосевной обработки семян // Наука и инновации. 2006. № 9 (43). С. 37-41.

8. Биологическая эффективность новых препаратов для предпосевной обработки семян в защите сеянцев от инфекционного полегания / В. А. Ярмолович [и др.] // Труды БГТУ. 2013. № 1: Лесное хоз-во. С. 262-265.

9. Винцит Форте [Электронный ресурс] // FMC. URL: http://www.fmcrussia.com/Средства-защиты-растений/Препараты/Обработка-семян/Винцит-Форте (дата обращения: 15.11.2019).

10. Экосил Микс [Электронный ресурс] // АгроБелорус. URL: https://agrobelarus.by/market/ polifunktsionalnye-prirodnye-preparaty/regulyator-rosta-rasteniy-ekosil-miks-ve-5g-1-triterpenovykh-kislot (дата обращения: 18.11.2019).

11. Экосил Плюс [Электронный ресурс] // АгроБелорус. URL: https://agrobelarus.by/market/polifunktsionalnyeprirodnye-preparaty/regulyator-rosta-rasteniy-ekosil-plyus-ve-2-5g-l (дата обращения: 18.11.2019).

12. Иванов В. Б. Практикум по физиологии растений. М.: Академия, 2001. 136 с.

13. Храмченкова О. М. Практикум по физиологии растений: практическое руководство. В 2 ч. Гомель: ГГУ, 2017. Ч. 1.44 с.

14. Коробко В. В., Касаткин М. Ю. Большой практикум по физиологии растений. Саратов: СГУ, 2017. $103 \mathrm{c}$.

15. Титова М. С. Содержание фотосинтетических пигментов в хвое Picea abies и Picea koraiensis // Вестник ОГУ. 2010. № 12. С. 9-12.

16. Колупаев Ю. Е. Активные формы кислорода в растениях при действии стрессоров: образование и возможные функции // Вестник Харьковского национального аграрного университета. Сер. Биология. 2007. № 3 (12). С. 6-26.

17. Гарифзянов А. Р., Жуков Н. Н., Иванищев В. В. Образование и физиологические реакции активных форм кислорода в клетках растений // Современные проблемы науки и образования. 2011. № 2. С. 100-120.

18. Сиделев С. И. Математические методы в биологии и экологии: введение в элементарную биометрию: учеб. пособие. Ярославль: ЯрГУ, 2012. 140 с.

\section{References}

1. Yakhin Oleg I., Lubyanov Aleksandr A., Yakhin Ildus A., Brown Patrick H. Biostimulants in Plant Science: A Global Perspective. Frontiers in Plant Science. 2017, vol. 7, pp. 1-32 (In English).

2. Volynets A. P., Shukanov V. P. Fiziologiya patogeneza i bolezneustoychivosti rasteniy [Pathogenesis physiology and disease resistance of plants]. Minsk, Bielaruskaya navuka Publ., 2016. 252 p.

3. Volynets A. P., Shukanov V. P., Polyanskaya S. N., Manzhelesova N. E., Korytsko L. A., Litvinovskaya R. P., Safonov D. P., Mashchenko N. E., Mel'nikova E. V., Lakhvich F. A., Goncharuk V. M., Golub I. A., Shanbanovich G. N., Savel'yev N. S. Endogennyye fitoregulyatory rosta: svoystva, fiziologicheskoye deystviye $i$ prakticheskoye ispol'zovaniye [Endogenous phytoregulators of growth: properties, physiological action and practical use]. Minsk, Bielaruskaya navuka Publ., 2019. 233 p.

4. Dudarevich V. I., Poznyak S. S., Romanovsky Ch. A. Influence of growth regulator in emerging ECOS, availability of the photosynthetic apparatus and the productivity of mid-potato varieties. Vestnik APK Verkhnevolzh'ya [APK Upper Herald], 2008, no. 1, pp. 19-24 (In Russian).

5. Chukicheva I. Yu., Khurshkainen T. V., Kuchin A. V. Natural regulators of plant growth from coniferous raw materials. Innovatika i ekspertiza [Innovation and expertise], 2018, no. 3 (24), pp. 93-99 (In Russian).

6. Raldugin V. A. Triterpenoids of fir and a highly efficient plant growth regulator based on them. Rossiyskiy khimicheskiy zhurnal [Russian Chemical Journal], 2004, no. 3, pp. 84-88 (In Russian).

7. Laman N. A., Alekseychuk G. N., Kalatskaya J. N. Modern technology for pre-sowing seed treatment. Nauka i innovatsii [Science and innovation], 2006, no. 9 (43), pp. 37-41 (In Russian).

8. Yarmolovich V. A., Dishuk N. G., Asmolovsky M. K., Semenova V. Yu. Biological effectiveness of new drugs for pre-sowing seed treatment in protecting seedlings from infectious lodging. Trudy BGTU [Proceedings of BSTU], 2013, no. 1: Forestry, pp. 262-265 (In Russian).

9. FMC. Vincit Forte. Available at: http://www.fmcrussia.com/Средства-защиты-растений/Препараты/Обработка-семян/Винцит-Форте (accessed 15.11.2019).

10. AgroBelorus. Ecosil Mix. Available at: https://agrobelarus.by/market/polifunktsionalnye-prirodnyepreparaty/regulyator-rosta-rasteniy-ekosil-miks-ve-5g-l-triterpenovykh-kislot (accessed 18.11.2019). 
11. AgroBelorus. Ecosil Plus. Available at: https://agrobelarus.by/market/polifunktsionalnye-prirodnyepreparaty/regulyator-rosta-rasteniy-ekosil-plyus-ve-2-5g-1 (accessed 18.11.2019).

12. Ivanov V. B. Praktikum po fiziologii rasteniy [Workshop on plant physiology]. Moscow, Akademiya Publ., 2001. 136 p.

13. Khramchenkova O. M. Praktikum po fiziologii rasteniy [Workshop on plant physiology]. Gomel', GGU Publ., 2017. 44 p.

14. Korobko V. V., Kasatkin M. Yu. Bol'shoy praktikum po fiziologii rasteniy [Large workshop on plant physiology]. Saratov, SGU Publ., 2017. 103 p.

15. Titova M. S. Content of photosynthetic pigments in the needles of Picea abies and Picea koraiensis. Vestnik OGU [Bulletin of OSU], 2010, no. 12, pp. 9-12 (In Russian).

16. Kolupaev Yu. E. Active forms of oxygen in plants under the action of stressors: formation and possible functions. Vestnik Khar'kovskogo natsional'nogo agrarnogo universiteta [Bulletin of Kharkov National Agrarian University], 2007, no. 3 (12), Biology, pp. 6-26 (In Russian).

17. Garifzyanov A. R., Zhukov N. N., Ivanishchev V. V. Formation and physiological reactions of reactive oxygen species in plant cells. Sovremennyye problemy nauki i obrazovaniya [Modern problems of science and education], 2011, no. 2, pp. 100-120 (In Russian).

18. Sidelev S. I. Matematicheskiye metody v biologii i ekologii: vvedeniye v elementarnuyu biometriyu [Mathematical methods in biology and ecology: an introduction to elementary biometrics]. Yaroslavl', YarGU Publ., 2012. 140 p.

\section{Информация об авторах}

Машкин Иван Анатольевич - младший научный сотрудник лаборатории физиологии патогенеза и болезнеустойчивости растений. Институт экспериментальной ботаники имени В. Ф. Купревича НАН Беларуси (220072, г. Минск, ул. Академическая, 27, Республика Беларусь). E-mail: ivan.mashkin.1993@gmail.com

Шуканов Владимир Петрович - кандидат биологических наук, заведующий лабораторией физиологии патогенеза и болезнеустойчивости растений. Институт экспериментальной ботаники имени В. Ф. Купревича НАН Беларуси (220072, г. Минск, ул. Академическая, 27, Республика Беларусь). E-mail: patphysio@mail.ru

Мельникова Елена Владимировна - научный сотрудник лаборатории физиологии патогенеза и болезнеустойчивости растений. Институт экспериментальной ботаники имени В. Ф. Купревича НАН Беларуси (220072, г. Минск, ул. Академическая, 27, Республика Беларусь). E-mail: patphysio@mail.ru

Корытько Лариса Александровна - научный сотрудник лаборатории физиологии патогенеза и болезнеустойчивости растений. Институт экспериментальной ботаники имени В. Ф. Купревича НАН Беларуси (220072, г. Минск, ул. Академическая, 27, Республика Беларусь). E-mail: patphysio@mail.ru

Полянская Светлана Николаевна - кандидат биологических наук, старший научный сотрудник лаборатории физиологии патогенеза и болезнеустойчивости растений. Институт экспериментальной ботаники имени В. Ф. Купревича НАН Беларуси (220072, г. Минск, ул. Академическая, 27, Республика Беларусь). E-mail: patphysio@mail.ru

\section{Information about the authors}

Mashkin Ivan Anatol'yevich - Junior Researcher, the Laboratory of Pathogenesis Physiology and Disease Resistance of Plants. V. F. Kuprevich Institute of Experimental Botany of the National Academy of Sciences of Belarus (27, Akademicheskaya str., 220072, Minsk, Republic of Belarus). E-mail: ivan.mashkin.1993@gmail.com

Shukanov Vladimir Petrovich - PhD (Biology), Head of the Laboratory of Pathogenesis Physiology and Disease Resistance of Plants. V. F. Kuprevich Institute of Experimental Botany of the National Academy of Sciences of Belarus (27, Akademicheskaya str., 220072, Minsk, Republic of Belarus). E-mail: patphysio@mail.ru

Mel'nikova Yelena Vladimirovna - Researcher, the Laboratory of Pathogenesis Physiology and Disease Resistance of Plants. V. F. Kuprevich Institute of Experimental Botany of the National Academy of Sciences of Belarus (27, Akademicheskaya str., 220072, Minsk, Republic of Belarus). E-mail: patphysio@mail.ru

Koryt'ko Larisa Aleksandrovna - Researcher, the Laboratory of Pathogenesis Physiology and Disease Resistance of Plants. V. F. Kuprevich Institute of Experimental Botany of the National Academy of Sciences of Belarus (27, Akademicheskaya str., 220072, Minsk, Republic of Belarus). E-mail: patphysio@mail.ru

Polyanskaya Svetlana Nikolayevna - PhD (Biology), Senior Researcher, the Laboratory of Pathogenesis Physiology and Disease Resistance of Plants. V. F. Kuprevich Institute of Experimental Botany of the National Academy of Sciences of Belarus (27, Akademicheskaya str., 220072, Minsk, Republic of Belarus). E-mail: patphysio@mail.ru 